\title{
Wage Concessions and Long-Term Union Wage Flexibility
}

BY MANY INDICATIONS, the behavior of average union wages in the early 1980s contrasts sharply with their behavior over most of the postwar period. During the 1970s the basic mechanisms of union wage determination were in many ways solidified: the average duration of labor agreements contirued to increase as the reach of multiyear contracts was extended, and there was a substantial expansion in the number of formal cost-of-living adjustment (COLA) provisions; many large unions adhered to a policy of negotiating an annual improvement factor plus COLA despite the fact that the productivity trends that formed the original justification for the annual improvement factor had greatly deteriorated; and while there has always been considerable dispersion in the results of individual negotiations, wage dispersion within the union sector appeared to increase as labor agreements that included COLA clauses ultimately yielded higher pay increases than those that did not. In addition, average union wage increases consistently exceeded average nonunion wage increases during the 1970s, raising the union-nonunion wage differential to a historic high by the early 1980 s.

All was not well within the union sector, however. The power of labor unions rests on their ability to sustain barriers to entry. Over the years different unions have sought to restrict nonunion competition in various ways, such as rationing access to training for some skills through apprenticeship programs, organizing all the producers of a particular

I am grateful to Frank Musick, Harriet Weinstein, and members of the Brookings Panel for comments, to Patricia J. Regan for careful research assistance, and to Susan L. Woollen and Anita G. Whitlock for text processing. 
product and its close substitutes in order to lower the elasticity of demand for their members' services, and trying to close off substitution possibilities by supporting protectionist trade policies.

During the late 1970s a confluence of events resulted in an unprecedented assault on union jurisdiction in several-but by no means allmajor industries. For the highly unionized airline and trucking industries, the challenge has come from new, domestic nonunion competition-the traditional source of challenge to union power-as deregulation removed barriers to entry into what are basically competitive markets. For the highly unionized "smokestack" industries, the challenge has come from the increasing share of American markets supplied by foreign producers. By 1980 , for example, imports accounted for 22 percent of the U.S. auto market, an increase of 83 percent over the import share in 1970. The import share of nonferrous metals more than doubled over the same period to about 18 percent. During the 1970s the import share also more than doubled in the apparel, textile, footwear, and metal machinery industries. ${ }^{1}$ Finally, the deep recession of the early 1980 s produced extensive layoffs and plant closings, adding to the market pressures on unions.

These events registered their first major effect on union power in a sequence of collective bargaining agreements in several industries, beginning in 1979 with the contract between the United Automobile Workers (UAW) and Chrysler Corporation. All told, these agreements yielded concessions in wages, fringe benefits, and a variety of work rules in exchange for slower rates of employment loss, commitments to divert labor-cost savings into investment and modernization, measures to increase the institutional security of unions (for example, management neutrality toward union organizing efforts at new plants), and mechanisms to provide at least partial restoration of wage and benefit concessions at some future date. ${ }^{2}$ The most immediate result of these develop-

1. In some cases the growth of imports was no doubt a response to the increased union relative wage. For example, by 1980 , average hourly earnings in the automobile industry relative to the private nonfarm sector generally had increased by 20 percent over the 196469 period. For steel and coal the comparable figures are 30 percent and 20 percent, respectively, by 1982. See Marvin H. Kosters, "Disinflation in the Labor Market," in William Fellner, ed., Essays in Contemporary Economic Problems: Disinflation (Washington, D.C.: American Enterprise Institute, 1984), pp. 247-86.

2. This was not the first instance of union contract concessions in the postwar period, but the scale of recent concessions bargaining is unprecedented. For a review of past 
ments has been that in the early 1980s, union wage adjustments have been a part of the general wage deceleration rather than a drag on it. I review this aspect of recent concession bargaining in the first section of the paper with particular attention to the gap between union and nonunion wages.

Another aspect of recent concession bargaining involves new means for adjusting pay to future contingencies. One novel feature of recent concessions is a willingness to incorporate compensation arrangements that effectively index part of the pay package to the performance of the firm. In the second section below, I consider this and other contingent pay arrangements embodied in recent concessions to evaluate whether they portend a durable change in the flexibility of union wages.

These relatively recent developments occur at a time when union membership in the private sector is at its lowest point since the late 1930s and early 1940s, when major union growth began. Unions tend to attribute their currently low membership to illegal activity by employers in resisting union organizing efforts. In addition, a series of decisions by the National Labor Relations Board and the Supreme Court appear to challenge some of the basic rights governing the collective bargaining relationship in the United States. In the final section of the paper, I examine the question of whether recent legal developments have altered the relative bargaining power of labor and management.

\section{Recent Wage Adjustments}

Several measures of wages and compensation reported in table 1 trace the general features of the wage acceleration of the late 1970s and deceleration of the early 1980s. Increases of the broadest indexeshourly compensation and hourly earnings-peaked in the 10-13 percent range in 1980 and then decelerated very rapidly to the 4-5 percent range by 1983 . At this level of aggregation, it appears that at least through 1982, wage behavior did not deviate significantly from the course implied by previous wage equations. ${ }^{3}$

episodes, see Daniel J. B. Mitchell, "Recent Union Contract Concessions," BPEA, 1:1982, pp. 165-201.

3. See George L. Perry, "What Have We Learned about Disinflation?" BPEA, 2:1983, pp. 587-602. 
Table 1. The Recent Deceleration of Wages and Compensation, 1976-83

Percent change

\begin{tabular}{|c|c|c|c|c|c|c|}
\hline Measure & $\begin{array}{c}1976-78 \\
\text { (average) }\end{array}$ & 1979 & 1980 & 1981 & 1982 & 1983 \\
\hline \multicolumn{7}{|l|}{ Hourly compensation index $x^{a}$} \\
\hline Nonfarm business sector & 8.2 & 9.2 & 10.8 & 9.0 & 7.2 & 4.8 \\
\hline Manufacturing & 8.4 & 9.8 & 12.7 & 8.8 & 7.2 & 4.7 \\
\hline Durable & 8.1 & 9.5 & 13.8 & 8.7 & 6.9 & 4.5 \\
\hline Nondurable & 8.2 & 10.5 & 11.2 & 9.0 & 8.7 & 4.5 \\
\hline \multicolumn{7}{|l|}{ Hourly earnings inde $x^{\mathrm{b}}$} \\
\hline Manufacturing & 8.4 & 8.9 & 10.6 & 8.6 & 6.0 & 2.8 \\
\hline \multicolumn{7}{|l|}{$\begin{array}{l}\text { Employment cost index, } \\
\text { wages and salaries }^{\mathrm{b}}\end{array}$} \\
\hline Private nonfarm sector & 7.3 & 8.7 & 9.0 & 8.8 & 6.3 & 5.0 \\
\hline Union & 7.8 & 9.0 & 10.9 & 9.6 & 6.5 & 4.6 \\
\hline Nonunion & 7.0 & 8.5 & 8.0 & 8.5 & 6.1 & 5.2 \\
\hline Manufacturing & 8.1 & 8.6 & 9.4 & 8.7 & 5.6 & 4.3 \\
\hline Union & 8.5 & 9.4 & 11.0 & 8.9 & 5.8 & 3.6 \\
\hline Nonunion & 7.7 & 7.9 & 7.9 & 8.3 & 5.6 & 4.7 \\
\hline Nonmanufacturing & 6.9 & 8.8 & 8.8 & 9.0 & 6.5 & 5.5 \\
\hline Union & 7.2 & 8.5 & 10.8 & 10.2 & 7.1 & 5.5 \\
\hline Nonunion & 6.8 & 8.8 & 8.1 & 8.6 & 6.2 & 5.5 \\
\hline State and local government & $\cdots$ & $\cdots$ & $\cdots$ & $\cdots$ & 6.5 & 5.3 \\
\hline \multicolumn{7}{|l|}{$\begin{array}{l}\text { Effective union wage } \\
\text { changes }^{\text {a }}\end{array}$} \\
\hline Private sector & 8.1 & 9.1 & 9.9 & 9.5 & 6.8 & 4.0 \\
\hline State and local government & $\ldots$ & 5.7 & 6.5 & 8.7 & 6.6 & 5.2 \\
\hline
\end{tabular}

Source: Hourly compensation and earnings indexes are from U.S. Bureau of Labor Statistics. Employment cost index is from Current Wage Developments, vol. 34 (May 1983), pp. 41-47. Effective union wage changes are from BLS, News, January 30 and February 23, 1984.

a. Fourth quarter to fourth quarter.

b. December to December.

\section{UNION AND NONUNION WAGE DEVELOPMENTS}

By removing the effects of employment shifts among occupations and industries, the U.S. Bureau of Labor Statistics (BLS) Employment Cost Index (ECI) provides a cleaner measure of wages and salaries and has the additional advantage of providing separate information on union and nonunion wage developments. ${ }^{4}$ These data reveal a more varied story of

4. The gaps in table 1 reflect the gaps in the development of the ECI. The series has included indexes of wages and salaries in the private sector since September 1975. Indexes of total compensation were added in late 1979 and 1980, and wage and compensation indexes for state and local government employees were begun in June 1981. 
the recent deceleration and the role of unions in that deceleration. Normally, nonunion wages have led the wage deceleration and displayed greater cyclical variance, while union wages, reflecting the influence of long-term contracts in which the wage provisions for later years are negotiated long before the economic environment of the increases is known, have tended to lag the deceleration in nonunion wages and have had less cyclical variance. In contrast to the usual pattern, union wages led nonunion wages in the deceleration of the early 1980s. In both the manufacturing and nonmanufacturing sectors, union wage increases peaked in 1980 , while nonunion wages continued to accelerate to a (lower) peak in 1981. Consistent with differences in union strength in the two sectors, overall wage increases in manufacturing peaked in 1980 with union wage increases and then began to decline despite the continued acceleration of nonunion wages, while increases in nonmanufacturing wages peaked in 1981 with nonunion wage increases.

The greater deceleration in 1982 and 1983 in manufacturing wages relative to nonmanufacturing appears to be entirely attributable to the relatively rapid deceleration of union manufacturing wages. (The deceleration of nonunion wages is essentially the same in each sector.) By 1983, wage increases in manufacturing were less for unionized workers than for nonunionized workers for the first time since 1969. It is more difficult to track the recent behavior of fringe benefits. Nevertheless, a comparison of the wage and salary data with the compensation data (not shown in the table) provided by the ECI indicates that outside of unionized manufacturing, the growth of fringe benefits has slowed less than the growth of wages.

The data in table 1 also reveal that recent union wage adjustments have only just begun to reverse the thirteen-year growth of the unionnonunion wage differential in manufacturing and have merely halted the recent growth of the differential in nonmanufacturing. Between 1969 and 1982, for example, the union-nonunion wage gap in manufacturing widened by 13.5 percentage points. ${ }^{5}$ It would take another decade of differences in union and nonunion wage growth of the size observed in 1983 to restore the relative union wage in manufacturing to its 1969 level.

5. The estimate is computed from the BLS Wage Developments in Manufacturing series for 1969-75 and from the Employment Cost Index for 1976-82. The former series can be found in George Ruben, "Observations of Wage Developments in Manufacturing during 1959-78," Current Wage Developments, vol. 33 (May 1981), pp. 47-59. 
Similarly, in nonmanufacturing, it would take at least a decade of unionnonunion wage growth differences of the dimensions observed in the late 1970 s to restore the union relative wage that existed at the beginning of 1980.

What is behind the unusually rapid recent deceleration in union wages? In an accounting sense, observed union wage behavior in any period reflects the weighted outcome of three components of union wages: (1) first-year wage changes negotiated in recent collective bargaining agreements, (2) deferred, fixed wage increases specified in contracts negotiated one or two years earlier, and (3) COLAs contingent upon the behavior of prices and the details of the negotiated formula that translates changes in consumer prices into wage adjustments. (The weights-the proportion of union workers receiving each type of increase-vary with the cycle of light and heavy bargaining years.)

The behavior of these three components is traditionally described in the following way. First-year negotiated wage changes are about as sensitive to unemployment as nonunion wage changes. However, the responsiveness of first-year increases is muted by the rigidities introduced by fixed, deferred increases. In addition, the combination of COLA clauses and adjustments to anticipated price increases built into fixed wage increases renders average union wages more responsive than nonunion wages to price changes. ${ }^{6}$ This behavior appears to have been altered somewhat in the early $1980 \mathrm{~s}$, but to understand how this occurred one must examine the three components of union wage adjustments. The ECI provides no information on these, but the BLS series on effective union wage adjustments does (see table 1). In the aggregate, this series parallels the ECI union wage change data but extends back to 1968 for the private sector. The 4.0 percent increase in 1983 was a historical low for the series.

The effective union wage change is decomposed into its three major components in table 2 and the components are graphed in figure 1. For most of the period the data are closely in accord with the traditional story. In particular, there is relatively little variance in the deferred union

6. See Robert J. Flanagan, "Wage Interdependence in Unionized Labor Markets," $B P E A, 3: 1976$, pp. 635-73; George E. Johnson, "The Determination of Wages in the Union and Non-union Sectors," British Journal of Industrial Relations, vol. 15 (July 1977), pp. 211-25; and Daniel J. B. Mitchell, Unions, Wages, and Inflation (Brookings Institution, 1980). 
Table 2. Components of Effective Union Wage Adjustments, 1969-83

\begin{tabular}{ccccc}
\hline & $\begin{array}{c}\text { Total } \\
\text { adjustment } \\
\text { (percent }\end{array}$ & \multicolumn{2}{c}{$\begin{array}{c}\text { Percentage points of total adjustment } \\
\text { attributable to components }\end{array}$} \\
\cline { 3 - 5 } Year & change) & $\begin{array}{c}\text { Current } \\
\text { settlements }\end{array}$ & $\begin{array}{c}\text { Prior } \\
\text { settlements }\end{array}$ & $\begin{array}{c}\text { Cost-of-living } \\
\text { adjustments }\end{array}$ \\
\hline 1969 & 6.5 & $2.4(36.9)$ & $3.8(58.5)$ & $0.3(4.6)$ \\
1970 & 8.8 & $5.1(55.4)$ & $3.1(33.7)$ & $0.6(6.5)$ \\
1971 & 9.2 & $4.3(46.7)$ & $4.2(45.7)$ & $0.7(7.6)$ \\
1972 & 6.6 & $1.7(25.8)$ & $4.2(63.6)$ & $0.7(10.6)$ \\
1973 & 7.0 & $3.0(42.8)$ & $2.7(38.6)$ & $1.3(18.5)$ \\
1974 & 9.4 & $4.8(51.1)$ & $2.6(27.7)$ & $1.9(20.2)$ \\
1975 & 8.7 & $2.8(32.2)$ & $3.7(42.5)$ & $2.2(25.3)$ \\
1976 & 8.1 & $3.2(39.5)$ & $3.2(39.5)$ & $1.6(19.8)$ \\
1977 & 8.0 & $3.0(37.5)$ & $3.2(40.0)$ & $1.7(21.2)$ \\
1978 & 8.2 & $2.0(24.4)$ & $3.7(45.1)$ & $2.4(29.3)$ \\
1979 & 9.1 & $3.0(33.0)$ & $3.0(33.0)$ & $3.1(34.1)$ \\
1980 & 9.9 & $3.6(36.4)$ & $3.5(35.4)$ & $2.8(28.3)$ \\
1981 & 9.5 & $2.5(26.3)$ & $3.8(40.0)$ & $3.2(33.7)$ \\
1982 & 6.8 & $1.7(25.0)$ & $3.6(52.9)$ & $1.4(20.5)$ \\
1983 & 4.0 & $0.8(20.0)$ & $2.5(62.5)$ & $0.6(15.0)$ \\
\hline
\end{tabular}

Source: Current Wage Developments, various issues.

a. Share of total adjustment in parentheses.

wage component, which often moves counter to first-year increases and mutes the aggregate response of union wages. The drag on the flexibility of union wage adjustments created by deferred increases from prior settlements is evident in the unusually high contribution of prior settlements to total effective wage changes in years in which the latter drop sharply $(1972,1982)$. The most dramatic secular feature of the data is the rise in the relative importance of COLA clauses during the 1970s. Accounting for less than 5 percent of effective wage changes in the late 1960 s, the contribution of COLAs increased rapidly in the early 1970s to about one-fifth of the change and then again around 1977-78 to account for about one-third of wage changes received by union workers before the trend was reversed in 1982 and 1983.

The current deceleration illustrates the complex interplay among the three components of union wages. Effective union wage gains peaked with the current settlements component in 1980. Between 1980 and 1981, however, the sharp 1.1 percentage point drop in the contribution of firstyear increases was largely neutralized by the continued acceleration of payments under deferred increases and COLAs. Only after 1981, when 
Figure 1. Components of Effective Union Wage Changes, 1969-83

Percent

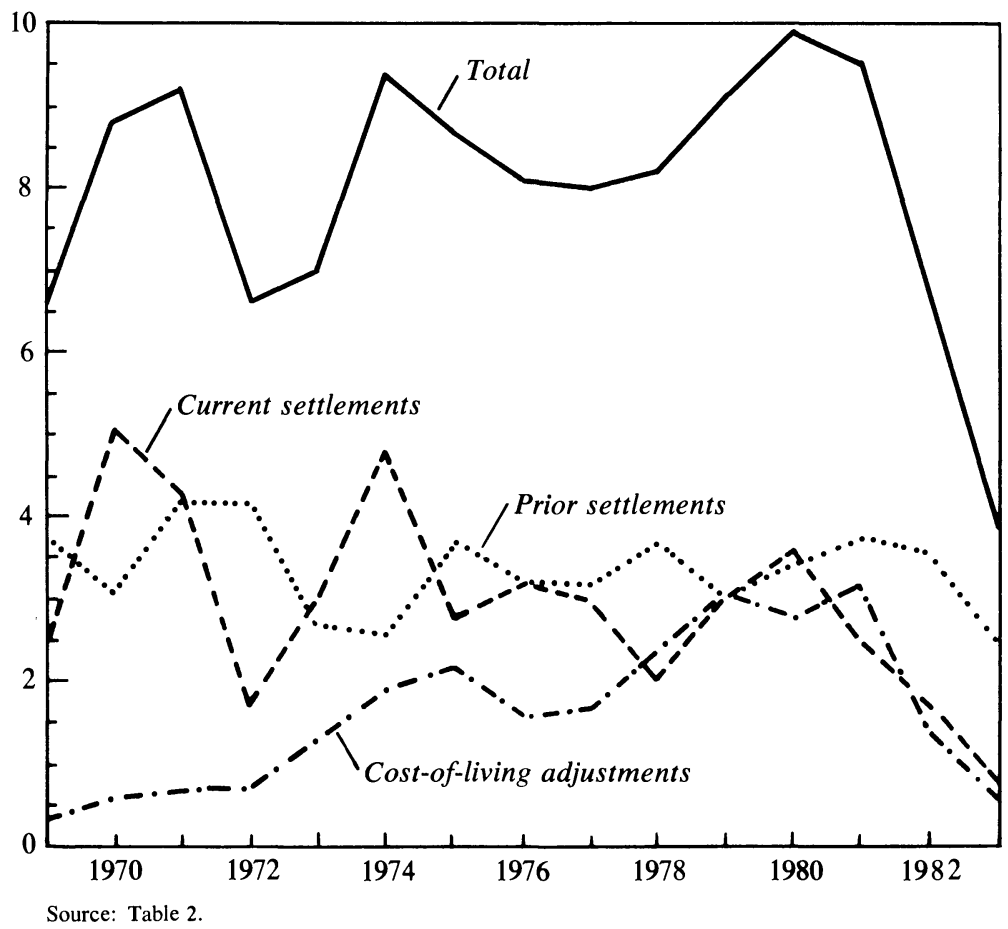

COLAs and, eventually, deferred increases began to decline, was there a substantial deceleration in the total.

A closer examination of the 1980-81 changes provides an interesting illustration of the effects of the contract cycle on aggregate union wage behavior. Between 1980 and 1981 the actual percentage wage changes received under each of the three categories of union wage adjustments moved in the opposite direction of the contribution of each category to the total wage adjustment shown in table 2 . The increase in first-year wage increases can be seen in table 3 , which is discussed more extensively in the next section. Table 2, however, shows that the movement of the individual components of effective union wage change were dominated by shifts in the proportions of union workers receiving each type of increase between 1980 (a relatively heavy bargaining year) and 1981 (a relatively light bargaining year). Although wage changes in the first year 
of new agreements increased between 1980 and 1981 (table 3), the proportion of union workers receiving such increases declined by a proportionately larger amount, pulling down the overall contribution of first-year increases to effective wages (table 2). Similarly, the increased contribution of deferred and COLA payments (where the percentage increase actually declined) was raised by the increased proportion of union workers receiving such payments. Therefore, union wages began to fall sooner (in relation to the rise in unemployment) in the recent recession than they had in past recessions largely because of the fortuitous timing of the bargaining cycle.

The 1982-83 deceleration in union wage gains differs from previous ones primarily in (1) the origin and extent of the decline in first-year wage increases and (2) the large drop in the COLA component. While concession bargaining played a role in each, the evidence suggests the results are unlikely to be durable.

\section{FIRST-YEAR INCREASES}

The dramatic deceleration of first-year union wage increases that initiated the fall in union wage increases in the early 1980 s reflects both the spread of unprecedented concessions and a general moderation of negotiated pay increases in industries where concessions were not made. Both the extent and nature of wage concessions has changed since the bargaining at Chrysler in 1979. Not only has the number of wage concessions expanded considerably, but the alterations in union contracts have become more dramatic. While early concessions tended to establish wage deferrals, there was a movement toward wage freezes and even wage cuts in later negotiations. There has also been a substantial increase in deferral or diversion of COLA payments over the period, which will be discussed further below. The impact of these developments on first-year wage settlements can be seen in table $3 .^{7}$

Wage decreases were essentially unheard of in major collective bargaining agreements until 1981. Two years later, a third of the workers in manufacturing covered by new agreements experienced wage reductions. Settlements in the steel, airline, and meatpacking industries during

7. In several instances, bargaining over concessions was initiated by reopening a labor contract before its scheduled expiration date. Since 1981, contracts resulting from such unscheduled reopenings have been treated as new agreements in the BLS data. 
Table 3. Distribution of Selected First-Year Wage Adjustments in Major Private-Sector Collective Bargaining Agreements, 1970-83

\begin{tabular}{|c|c|c|c|c|c|}
\hline \multirow[b]{2}{*}{ Wage adjustment } & \multicolumn{5}{|c|}{ Percent of unionized private-sector workers } \\
\hline & $\begin{array}{l}\text { 1970-79 } \\
\text { (average) }\end{array}$ & 1980 & 1981 & 1982 & 1983 \\
\hline \multicolumn{6}{|l|}{ Decrease } \\
\hline Total & 0 & 0 & 5.0 & 2.0 & 15.0 \\
\hline Manufacturing & 0 & 0 & 9.0 & 2.0 & 32.0 \\
\hline Nonmanufacturing & 0 & 0 & 2.0 & 2.0 & 7.0 \\
\hline Construction & $0^{\mathrm{a}}$ & 0 & 1.0 & 4.0 & 13.0 \\
\hline \multicolumn{6}{|l|}{ No change } \\
\hline Total & 2.0 & 0 & 3.0 & 42.0 & 22.0 \\
\hline Manufacturing & 1.0 & 0 & 4.0 & 50.0 & 24.0 \\
\hline Nonmanufacturing & 4.0 & 0 & 2.0 & 33.0 & 20.0 \\
\hline Construction & $4.0^{\mathrm{a}}$ & 0 & 0 & 10.0 & 43.0 \\
\hline \multicolumn{6}{|l|}{$\begin{array}{l}\text { Increase of } 10 \\
\text { percent or more }\end{array}$} \\
\hline Total & 31.0 & 35.0 & 63.0 & 8.0 & 5.0 \\
\hline Manufacturing & 27.0 & 26.0 & 47.0 & 2.0 & 5.0 \\
\hline Nonmanufacturing & 35.0 & 44.0 & 71.0 & 13.0 & 4.0 \\
\hline Construction & $22.0^{\mathrm{a}}$ & 79.0 & 76.0 & 20.0 & 4.0 \\
\hline \multicolumn{6}{|l|}{$\begin{array}{l}\text { Addendum: Mean } \\
\text { adjustment (percent) }\end{array}$} \\
\hline Total & 8.8 & 9.5 & 9.7 & 3.8 & 2.6 \\
\hline Manufacturing & 8.2 & 7.4 & 7.2 & 2.8 & 0.3 \\
\hline Nonmanufacturing & 9.2 & 10.9 & 11.2 & 4.8 & 3.8 \\
\hline Construction & 8.8 & 13.6 & 13.5 & 6.5 & 1.5 \\
\hline
\end{tabular}

Source: Current Wage Developments, various issues.

a. Average for 1973-79.

1983 have called for first-year wage reductions ranging from 10 to 20 percent. Indeed, under the impact of the steel agreement in early 1983, the median wage adjustment in 1983 for all major collective bargaining agreements was a negative 3.7 percent in the first quarter of 1983 . Wage freezes in collective bargaining settlements were also rare before 1982; yet in that year half of the first-year settlements in major manufacturing collective bargaining agreements provided for no wage change. The decline in the proportion of manufacturing workers under new agreements providing for wage freezes in 1983 was more than offset by the increase in the proportion receiving wage reductions. By 1983 wage freezes or reductions also applied to more than half the workers covered by new agreements in the construction industry. All told, first-year wage 
concessions granted in major private-sector collective bargaining agreements renegotiated in 1982 and 1983 applied to approximately 40 percent (2.6 million) of the workers covered by such agreements. ${ }^{8}$ More than half of the workers in large bargaining units in manufacturing appear to be subject to concessions. Many of the contracts providing for freezes or reductions in the first year provide for pay increases in later years of the contract. As will become apparent below, however, some of these future increases are contingent on the future performance of the firms in which union workers are employed.

The objectives of both labor and management are important in determining the strife and outcomes of collective bargaining. Although employers in several industries were pushed by increasing competition to reduce labor costs, it is clear from the recent record on strike activity that the wage concessions occurred in an environment of reduced union militancy. If union militancy had remained unchanged, efforts to cut pay would have been accompanied by an increase in strike activity. Instead, work stoppages have been at postwar lows since 1981. In 1981 the BLS reported 2,577 work stoppages involving six or more workers. ${ }^{9}$ One has to go back to the late 1930s, when the extent of union organization was much smaller than it is now, to find years in which work stoppages were this low. Because of budget reductions, the scope of the series was limited to stoppages involving 1,000 or more workers beginning in 1982 . For 1981, 1982, and 1983, the respective number of work stoppages reported in this series is 145,96 , and 81 . Again, figures this low had not been recorded for this series since the late 1930s. ${ }^{10}$

It is important to note that there is considerable variation in effective union wage changes around the deceleration in the average. The most dramatic concessions have been limited to a few major industriesautomobiles, steel, rubber, airlines, railroads, trucking, meatpacking,

8. Interestingly, on the basis of a more detailed examination of individual labor agreements signed between 1979 and 1982, Kosters arrives at an almost identical estimate (2.5 million) of the number of workers in major agreements subject to concessions (defined as wage and benefit decisions involving reductions, no change, deferrals, or smaller increases than would have been provided under previous contractual pay formulas). Kosters, "Disinflation in the Labor Market," p. 269.

9. Although the work stoppage data technically include employer lockouts of their employees, the latter constitute a very small proportion of total stoppages.

10. Data are from Current Wage Developments, vol. 34 (February 1982), pp. 17-19, and vol. 36 (February 1984), p. 20. 
supermarkets, and construction. The product market pressures experienced in these industries, with the exception of construction, are not fundamentally cyclical. During the 1970s, some of the industries came under increased pressure from international competition, a factor that was intensified in the early 1980s with the overvaluation of the dollar. In addition, deregulation reduced barriers to entry in the airlines and surface transportation. In the meatpacking industry, new nonunion plants with advanced technology challenged the markets of older, high-cost, unionized plants. Each of these developments would have placed unions in the affected industries under considerable pressure to proffer concessions that would reduce unit labor costs even in the absence of the recession. ${ }^{11}$ The result of the uneven impact of product market pressures was that at a time when the median union worker in manufacturing was experiencing no change in wage, some workers were receiving first-year increases in excess of 10 percent (table 3). While the upper tail of the wage-change distribution seemed to collapse in 1982 as settlements in excess of 10 percent all but disappeared outside of construction, it nevertheless dropped less rapidly than the median, and the overall dispersion of wage changes increased. Of those receiving wage decreases in manufacturing (nonmanufacturing) in 1983, for example, the median decrease was -6.6 percent $(-4.0$ percent). On the other hand, for those receiving an increase, the median was 5.2 percent ( 5.8 percent).

The dispersion in union wage adjustments both recently and during the 1970s contradicts the view that a few key settlements are widely imitated throughout the economy. While some patterns persisted (even in granting concessions) where one would most expect to observe themamong firms competing in the same product markets-there were dropouts of the most severely afflicted firms from the historical pattern (such as Chrysler in the automobile industry), and effective patterns were further diminished by the adoption of profit-sharing plans (discussed below). In addition, the effective union wage change data confirms the earlier implication in the ECI data that the union wage deceleration is not uniform but has been concentrated in manufacturing. Effective union wage changes in that sector moved from 5.2 percent in 1982 to 2.6

11. For an estimate of the effect of import penetration on the probability of concession bargaining, see Peter Cappelli, "Concession Bargaining and the National Economy," 35th Annual Proceedings of the Industrial Relations Research Association (IRRA, 1983), pp. $362-71$. 
Table 4. Distribution of Selected First-Year Wage and Compensation Adjustments in State and Local Government Collective Bargaining Agreements, 1979-83

\begin{tabular}{|c|c|c|c|c|}
\hline \multirow[b]{2}{*}{ Year } & \multicolumn{2}{|c|}{$\begin{array}{l}\text { Percent of workers } \\
\text { by size of settlement }{ }^{\mathrm{a}}\end{array}$} & \multirow[b]{2}{*}{$\begin{array}{c}\text { Mean } \\
\text { adjustment } \\
\text { (percent) }\end{array}$} & \multirow[b]{2}{*}{$\begin{array}{c}\text { Median } \\
\text { adjustment } \\
\text { (percent) }\end{array}$} \\
\hline & No change & $\begin{array}{l}\text { Increase of } \\
10 \text { percent } \\
\text { or more }\end{array}$ & & \\
\hline \multicolumn{5}{|l|}{1979} \\
\hline Wage & 4.0 & 8.0 & 6.8 & 7.0 \\
\hline Compensation & 0.0 & 7.0 & 7.0 & 6.8 \\
\hline \multicolumn{5}{|l|}{1980} \\
\hline Wage & 10.0 & 12.0 & 7.5 & 8.0 \\
\hline Compensation & 3.0 & 7.0 & 7.3 & 7.6 \\
\hline \multicolumn{5}{|l|}{1981} \\
\hline Wage & 9.0 & 21.0 & 7.4 & 8.0 \\
\hline Compensation & 2.0 & 21.0 & 7.8 & 7.7 \\
\hline \multicolumn{5}{|l|}{1982} \\
\hline Wage & 12.0 & 11.0 & 7.2 & 8.0 \\
\hline Compensation & 10.0 & 12.0 & 7.4 & 7.7 \\
\hline \multicolumn{5}{|l|}{1983} \\
\hline Wage & 21.0 & 0.0 & 4.4 & 5.0 \\
\hline Compensation & 2.0 & 0.0 & 4.6 & 5.0 \\
\hline
\end{tabular}

Source: BLS, "State and Local Collective Bargaining Settlements, 1983," News, February 23, 1984.

a. There were no significant wage decreases in state and local government collective bargaining agreements during this period.

percent in 1983 but only from 7.8 to 6.9 percent in services. Moreover, the continual increase in the union-nonunion wage differential during the 1970s indicates the limited influence of union agreements in the nonunion sector.

No parallel deceleration of wages and benefits is discernible in publicsector collective bargaining until 1983. Since 1979 , the BLS has published data on wage and benefit changes in collective bargaining agreements covering at least 5,000 state and local government employees (about a quarter of all such workers covered by such agreements). Data on firstyear wage and compensation changes appear in table 4 . There are no instances of wage reductions. There has been a gradual increase in the share of these workers receiving no change in wages or benefits, but this share remains well below that observed in the private sector.

One reason that the public sector had higher and less flexible wage 
changes than the private sector during the period is the fact that COLAs were eliminated from major public-sector labor agreements during the early 1980s in exchange for larger fixed-wage increases. In 1979 sixteen major agreements had COLAs, covering about a quarter of the workers in state and local government bargaining units with more than 5,000 workers. By the end of 1983 only one remained in effect (covering about 1 percent of the workers in such units).

\section{Contingent Compensation}

The deceleration of first-year wage adjustments in the early 1980s has been dramatic, but in large measure is more an extension than a break with past union wage behavior. As already noted, this part of union wages has always been sensitive to the economic environment, and if a system of fixed (noncontingent) wage changes is maintained, first-year wage increases in industries where concessions have been granted will in all likelihood accelerate if and when profitability is restored. It has been through contractual devices such as COLAs and annual improvement factors that union wages have resisted downward pressure, moved up with inflation, and grown relative to nonunion wages. And it is contractual alterations in the means by which union wages adjust to contingencies that hold the most promise for greater macroeconomic wage flexibility and a reduction in the union-nonunion wage gap. In this section, we examine the extent to which such alterations have occurred in recent concession bargaining.

While the most obvious structural adjustment to greater uncertainty is to negotiate more frequently, labor and management have generally abandoned this option during the postwar period on the grounds that negotiating costs, including the probability of strikes, rise with the frequency of negotiations. There has been no discernible tendency toward this option during the recent wave of concession negotiations. The average duration of major private-sector labor agreements negotiated in 1982 and 1983 was 31 and 32 months, respectively, only slightly below the peak of 33.4 months in 1979 and at about the average of the 1970s.

Within the regime of long-term labor agreements, the parties have generally adjusted to the future by a system of deferred noncontingent 
wage increases and COLAs providing wage payments dependent on the movement of a general price index. The drag imposed on general union money wage movements by these mechanisms was evident in data reviewed in the previous section. Thus, one of the more important questions for future union wage behavior is the extent to which concession bargaining has altered or found substitutes for COLAs and noncontingent deferred wage increases in the later years of long-term labor agreements.

\section{COLA ADJUSTMENTS}

The first section showed that after a decade of increase, there was a sharp decline in effective union wage increases attributable to COLAs. Here I examine whether this development was caused by changes in the tendency of unions and management to index part of compensation to general price movements, or was simply a byproduct of the general price deceleration.

In an accounting sense, the observed contribution of COLAs, $w^{c}$, to total effective union wage changes has three components: (1) the proportion of union workers covered by COLAs, $a$, (2) the proportion of price change provided as compensation to workers covered by COLA formulas (degree of compensation), $k$, and (3) the rate of change in consumer prices, $p$. The contribution of COLAs to effective wage changes can be roughly expressed by the following equation: $w^{c}=a k p$. (In practice, the nature of most COLA formulas results in a nonlinear relationship between $k$ and $p$. $)^{12}$

Historical data on these components of COLA are presented in table 5. Note first that the growth in the COLA component of effective union

12. Thus the major contractual changes that might contribute to the recent decline in the contribution of COLAs to effective wage changes are a decline in the proportion of workers covered by COLAs, or a change in the degree to which COLA formulas compensate workers for price changes, or both. Among the sources of nonlinearity in the compensation parameter are the fact that most COLA formulas provide for equal centsper-hour increases for a fixed percentage point change in the reference price index, changes in the mix of review periods, and the existence of caps and floors in the COLA formulas. More than 20 percent of the COLAs have caps, a proportion that is little changed since 1978. Caps were found in about two-thirds of the COLA arrangements in the late 1960s but were rapidly dropped from collective bargaining agreements during the inflation of the early 1970s. Floors are found less frequently (in about 7-10 percent of major agreements). 
Table 5. Decomposition of Cost-of-Living Adjustment (COLA) Component of Effective Annual Wage Changes, 1968-83

Percent

\begin{tabular}{|c|c|c|c|c|}
\hline Year & $\begin{array}{c}\text { Wage change } \\
\text { due to COLAs, } \\
w^{c}\end{array}$ & $\begin{array}{l}\text { Unionized work- } \\
\text { ers covered by } \\
\text { COLAs, a }\end{array}$ & $\begin{array}{l}\text { Degree of com- } \\
\text { pensation, }{ }^{\mathrm{a}} k\end{array}$ & $\begin{array}{c}\text { Price } \\
\text { change, }{ }^{\mathrm{b}} p\end{array}$ \\
\hline 1968 & n.a. & 23.6 & n.a. & 4.7 \\
\hline 1969 & 0.3 & 25.0 & n.a. & 6.1 \\
\hline 1970 & 0.6 & 25.9 & n.a. & 5.5 \\
\hline 1971 & 0.7 & 27.8 & n.a. & 3.4 \\
\hline 1972 & 0.7 & 40.6 & n.a. & 3.4 \\
\hline 1973 & 1.3 & 39.4 & n.a. & 8.8 \\
\hline 1974 & 1.9 & 39.2 & n.a. & 12.2 \\
\hline 1975 & 2.2 & 51.5 & n.a. & 7.0 \\
\hline 1976 & 1.6 & 59.4 & n.a. & 4.8 \\
\hline 1977 & 1.7 & 61.2 & n.a. & 6.8 \\
\hline 1978 & 2.4 & 60.4 & n.a. & 9.0 \\
\hline 1979 & 3.1 & 58.9 & n.a. & 13.3 \\
\hline 1980 & 2.8 & 58.1 & n.a. & 12.4 \\
\hline 1981 & 3.2 & 58.2 & 67.0 & 8.9 \\
\hline 1982 & 1.4 & 56.7 & 70.0 & 3.9 \\
\hline 1983 & 0.6 & 57.6 & 53.0 & 3.8 \\
\hline
\end{tabular}

Source: COLA wage change and degree of compensation are from Current Wage Developments, various issues; COLA coverage is from Monthly Labor Review, vol. 106 (January 1983), p. 11, and previous January issues; price change is from Economic Report of the President, February 1984, p. 283.

n.a. Not available.

a. Proportion of price change provided as compensation to workers covered by COLAs.

b. December-to-December change in CPI-U.

wage changes recorded in table 2 and figure 1 reflects a combination of increasing inflation and expanding COLA coverage during the first half of the 1970s; from 1977 (when COLA coverage peaked) through 1981 it reflected the acceleration of inflation alone. ${ }^{13}$ Second, the recent deceleration in the role of COLAs in union wage adjustments cannot be attributed to a tendency for union workers to give up the COLA provisions of their collective bargaining agreements. The coverage proportion, $a$, has remained in the region of 60 percent since 1976. Nor has there been a general tendency to give up COLAs in industries in which the most substantial wage concessions have been negotiated. Data on the extent of COLA coverage in these industries in recent years

13. Data on the degree of compensation are not available until 1981 and are not as easily computed. Rough estimates indicate that this parameter did not vary much during the 1970s. 
Table 6. Percent of Union Workers Covered by Cost-of-Living Adjustment Clauses, Selected Industries, 1979-83

\begin{tabular}{lrrrrr}
\hline \multicolumn{1}{c}{ Industry } & 1979 & 1980 & 1981 & 1982 & 1983 \\
\hline All industries & 59 & 58 & 58 & 57 & 58 \\
Building construction & 2 & 7 & 7 & 7 & 9 \\
Food products & 36 & 32 & 31 & 50 & 44 \\
Rubber and plastic & 88 & 82 & 92 & 90 & 89 \\
Primary metals & 96 & 95 & 95 & 96 & 95 \\
Transportation equipment & 94 & 94 & 87 & 87 & 94 \\
Motor freight transportation & 98 & 98 & 99 & 100 & 100 \\
Transportation by air & 72 & 79 & 70 & 40 & 13 \\
Food stores & 71 & 63 & 39 & 38 & 19 \\
\hline
\end{tabular}

Source: Monthly Labor Review, vol. 107 (January 1984), p. 30, and previous January issues.

a. Contracts covering 1,000 or more workers.

appear in table 6. Although COLA coverage is extensive in several of these industries, the only substantial abandonment of COLAs that is discernible during the recent period of concession bargaining is in the airlines and in food stores. Whatever the pressures on recent collective bargaining, they have not led workers to give up the basic contractual provisions indexing wages to movements in the general price index.

Instead, several unions have agreed to temporarily forgo or defer COLA payments, to reduce the frequency of review periods, or to divert some of the accrued payments to other purposes, such as maintenance of certain fringe benefits. In addition, there has been some tendency to lengthen the period between COLA reviews. Between 1981 and 1983, the share of indexed workers that had a COLA review scheduled during the year declined from 68 percent to 59 percent, but in 1984, 86 percent of the workers are scheduled for a review. Relative to the early 1980s, a higher proportion of COLA contracts provide for (less expensive) annual reviews and a lower proportion for quarterly or semiannual reviews, but these proportions are similar to those in effect in 1978. The impact of these largely temporary adjustments should be on the degree of compensation.

The degree of compensation ( $k$ in the equation above) is difficult to derive, since it reflects the different review periods established in different collective bargaining agreements as well as the specific characteristics of the COLA formula, such as floors and ceilings. As noted above, the compensation parameter is unlikely to be linear in prices. The BLS has published estimates of $k$ based on the exact contractual 
COLA formulas in major collective bargaining agreements and the actual reference periods used in determining COLA payments since 1981 (table 5). These data reflect only COLA provisions and therefore do not include compensation for price increases that may be embedded in fixed wage increases. By the early 1980s, COLAs compensated on average for about two-thirds of changes in the CPI. In 1983, however, the compensation provided by adjustments from COLA clauses dropped to little more than half of changes in the CPI. This change reflects the largely one-time alterations in COLA payments noted above as well as the possibly more permanent alterations in review periods and price movements that were too small to trigger COLA payments. The basic structure of most COLA formulas has not been altered substantially during the period of concession bargaining.

The evidence indicates that the deceleration in the COLA component of union wage adjustments in the early 1980 s was initially and mainly a result of the deceleration of the CPI. Later, and of secondary importance, specific, one-time concessions achieved a temporary reduction in the degree of compensation provided by COLAs to workers in a few industries in extreme economic distress. Nevertheless, the pressures that have stimulated wage concessions have not significantly altered the contractual methods by which management and labor address future price uncertainty. COLA clauses have been eliminated from only a few major agreements in the private sector, and these changes have essentially been offset by the adoption of new COLA clauses in other bargaining relationships. Moreover, there has been little tendency to renegotiate the parameters of COLA formulas. Even in those industries in which the most substantial concessions have been negotiated, basic structural changes in COLAs have not usually been an element of the concession package. Therefore, there is little reason to expect that the role of COLAs in union wage determination will be substantially altered in the near future. ${ }^{14}$

14. Whether there is a reduction in COLA coverage over the longer term depends on a difficult-to-forecast set of factors including uncertainty concerning expected inflation rates, the degree of unexpected inflation, the sensitivity of asset values to price changes, and the change in a firm's value added with respect to general price changes. See Ronald G. Ehrenberg, Leif Danziger, and Gee San, "Cost-of-Living Adjustment Clauses in Union Contracts: A Summary of Results," Journal of Labor Economics, vol. 1 (July 1983), pp. 215-45; Wallace E. Hendricks and Lawrence M. Kahn, "Cost-of-Living Clauses in Union Contracts: Determinants and Effects," Industrial and Labor Relations Review, vol. 36 
In recent years, several economists have noted the desirable macroeconomic properties of indexing compensation to some measure of firm performance and have suggested that an answer to stagflation is to be found in a revision of compensation systems. ${ }^{15}$ Institutional arrangements with this character include indexing wages to output price, profit sharing, employee stock ownership plans, and the ultimate in such plans, employee ownership of the firm.

Such compensation arrangements are logically distinct from the worker participation or codetermination plans, common in many European countries, which provide for employee representation on supervisory boards and works councils; as will become apparent below, however, there are reasons to expect complementarities between performancebased compensation schemes and participation arrangements.

Compensation systems that link pay to the performance of the firm also have the potential for producing long-run productivity gains for the firm. With pay linked to the profitability of the firm, workers have a general incentive to increase effort, relax or abandon restrictive work rules, and take other actions that contribute to the efficiency of the firm. The strength of these incentives generally depends on the size of the organization and on the specific structure of the compensation system. One recurrent difficulty with actually realizing the potential gains is that performance-based compensation arrangements have important public-good characteristics, with a consequent potential for freerider behavior. As a result, some performance-based systems may significantly increase short-run wage flexibility without having much of an impact on the long-run efficiency of organizations.

American unions and management have been reluctant historically to

(April 1983), pp. 447-60; and Jean-Michel Cousineau, Robert Lacroix, and Danielle Bilodeau, "The Determination of Escalator Clauses in Collective Agreements," Review of Economics and Statistics, vol. 65 (May 1983), pp. 196-202.

15. See, for example, Martin L. Weitzman, "Some Macroeconomic Implications of Alternative Compensation Systems,"' Economic Journal, vol. 93 (December 1983), pp. 763-83; James E. Meade, "The Adjustment Process of Labour Co-operatives with Constant Returns to Scale and Perfect Competition, ' Economic Journal, vol. 89 (December 1979), pp. 781-88; and James E. Meade, Stagflation, vol. 1: Wage Fixing (London: Allen and Unwin, 1982). 
index the compensation of union members to the fortunes of the firms that employ them, through profit sharing or stock ownership. ${ }^{16}$ On the union side, such arrangements conflict with several traditional objectives. With interfirm variations in performance, for example, these compensation systems thwart the basic union goal of "taking the wage out of competition" and break whatever intra- and interunion wage patterns may have developed as part of an effort to secure this objective. Indexing to firm performance also creates more uncertainty over real income than does the more traditional indexation of compensation to a general price index. Unless the firm's performance is closely correlated with the general price index, a COLA will provide a greater degree of real wage insurance.

Faced with these uncertainties, the median union voter, whose preferences determine the nature of the labor contract that will be ratified, is unlikely to support performance-based compensation systems in normal times. Protected by seniority arrangements from layoffs during moderate cyclical fluctuations, the median union voter recognizes a fixed-wage policy for what it is-a fixed (nominal) income policy for all but the least senior workers. When major secular or cyclical economic developments result in plant closings and layoffs that threaten the employment and earnings of even the median voter, however, performance-based compensation arrangements that might mitigate expected income losses may be considered in a new light.

Developments in labor contracts during the early 1980s are consistent with this view of union decisionmaking. Various arrangements that index compensation to the fortunes of the firm have been a feature in the concession bargaining of the early 1980s. However, neither the indexing nor the wage concessions for which it is often a quid pro quo has been a general phenomenon. As the median-voter model would predict,

16. In 1980, for example, only 1 percent of major collective bargaining agreements in the private sector included profit-sharing plans as part of worker compensation. Another 2 percent of the agreements provided for employee stock ownership plans under which workers could purchase shares of company stock, usually under more favorable terms than are available on the open market. Fewer than 200,000 workers were covered by agreements with such plans. BLS, Characteristics of Major Collective Bargaining Agreements, January 1, 1980, Bulletin 2095 (Government Printing Office, 1981). In a broader sample of large and medium-size firms in 1980, 13 percent of production workers were eligible to participate in profit sharing and 24 percent were eligible to participate in various stock-ownership plans. Separate percentages for union and nonunion workers were not available. BLS, Employee Benefits in Industry, 1980, Bulletin 2107 (GPO, 1981), p. 31. 
they are concentrated in the industries that were subject to extreme product market pressures (such as autos, steel, airlines, meatpacking, and rubber). I will review the main features of some of the more important types of performance-based compensation arrangements negotiated by unions in recent years because of their potential importance for greater wage flexibility and greater long-run efficiency.

Profit Sharing. Profit sharing has been the main approach to performance-based compensation negotiated by unions in recent years. Most of the plans require the firm to earn a certain minimum annual return (MAR), usually based on pretax profits, before the profit-sharing features of the compensation package are invoked. Once the MAR is reached, the key features of the plans are those determining (1) how the pool of profits available for sharing is determined and (2) how the pool is to be distributed among eligible individuals. ${ }^{17}$ These features determine the plan's potential for creating wage flexibility and efficiency.

Only a few of the recently negotiated plans provide profit sharing from the first dollar of profits. Instead, most plans provide that pretax profits must reach a contractually specified MAR - variously defined as a percentage of sales (the UAW-Ford Motor Company agreement), sales plus net worth (the UAW-Caterpillar Tractor Company agreement), or net worth plus liabilities (the UAW-General Motors Corporation agreement). While the MAR delays the point at which wages increase in response to profits, it also limits the extent to which wages fall in response to cyclical reductions in profits.

To fund the profit-sharing pools, several recent agreements call for allocating a fraction of pretax profits above the MAR to a pool for distribution to workers. Some plans use a fixed fraction and others (such as UAW-Ford) use a tiered approach, in which the percentage of profits available for distribution to employees increases in steps with the profit rate earned by the company.

Other contracts take a "deferred entitlement" approach, in which the amount that may be returned to workers from profits is equal to the amount of their earlier wage concessions. Under this approach, taken in the agreement between the United Steelworkers and the WheelingPittsburgh Steel Corporation, wages forgone by workers are in effect "loaned" to the company. Workers receive a contractual right to the

17. Most of the plans distribute the proceeds in cash, although some allow workers the option of cash or stock purchase. 
amount of their wage concession and are in effect placed in the position of preferred stockholders. The funds available for redistribution may be created by profits in excess of MAR, but the total available for profit sharing is limited by the amount of the initial concessions. While the arrangement may provide incentives for short-term gains in efficiency to hasten the time at which the concessions are returned, its long-term incentive effects are dubious.

Profit-sharing plans recently negotiated in the agricultural and construction equipment industry provide an open-ended fund. Indeed, the funding and the distribution are synonymous in these cases once a firm exceeds the MAR: workers receive a cents-per-hours-worked payment whose size depends on the firm's profit rate. (In a similar plan, pilots with Pan American World Airways will receive a 1 percent pay increase for every $\$ 20$ million of operating profit earned after interest.) This variant is much like a straight bonus system.

The mechanism for distributing profit-sharing funds to individual workers in recent collective bargaining agreements typically calls for a guaranteed amount plus a variable payment. An interesting feature of some of these plans is the size of the guaranteed payment in the first year of the agreement. In the farm and construction equipment industries, for example, the guarantees are based on what the negotiated profitsharing plans would have yielded if they had been in effect during 197781. Profits during that period appear to be larger than are likely to occur in the first year of the current plan. Guarantees in the automobile industry plans do not appear to be as large. Nevertheless, at least for the first contract year, some negotiated profit-sharing plans appear to have little to do with indexing compensation to the current fortunes of the firm. The large guarantees convert them instead into another form of fixed annual improvement factor.

In agreements with a fixed rather than open-ended pool, eligible workers also receive a share of the pool that is equal to their share of hours paid or compensation received, depending on the plan. The exact mechanism used for this variable payment has implications for the wage structure and for the future pattern of support within the union for the profit-sharing arrangement. Consider a plan in which distribution is based solely on an individual's share of hours paid. ${ }^{18}$ Different individuals

18. This is the distribution formula in the current UAW-General Motors agreement, for example. 
paid for the same number of hours will receive the same profit-sharing payment in absolute terms, regardless of their skill level or base rate. Like the historically common practice of negotiating equal absolute wage increases and structuring COLAs to provide equal cents-per-hour adjustments for price changes, this distribution mechanism tends to narrow wage differentials based on skill. Thus, the impact of the profitsharing arrangement is similar to that of the fixed wage increases that it supplants. It also runs counter to the efforts of some employers to widen wage differentials by skill in order to provide greater incentives for training. A second characteristic of a distribution mechanism based on a worker's share of total hours is that such incentive effects as exist will be strongest for relatively low skilled workers, for whom the profitsharing component of compensation is relatively large. By extension, free-rider responses would be relatively large among high-skilled workers. For the same reason, the rank and file of unions adopting profitsharing plans with this particular distribution mechanism are likely to be less unified about the desirability of retaining the arrangement in future negotiations. Indeed, the likelihood of retaining the practice will depend on the exact skill (wage) distribution of union members.

Consider instead a profit-sharing plan in which the fund is distributed according to an individual's pro rata share of total compensation. ${ }^{19}$ For a given number of hours of work, each worker will receive a profitsharing payment in proportion to his or her wage rate and the profitsharing component of compensation will not operate to narrow the structure. In this instance, workers should have an equal stake in the profit-sharing plan regardless of skill level, and the prospects for its retention in the future should be higher.

Negotiated Profit Sharing Plans and Union Wage Flexibility. The profit-sharing arrangements that have been negotiated in several industries in recent years have the potential for increasing the responsiveness of union wages to the firm's performance. Nevertheless, several factors are likely to limit the effect of the plans on aggregate union wage flexibility.

First, the coverage of the plans, while much broader than only a few years ago, is limited to the short list of industries noted above, and within these industries, coverage is not complete. I estimate that about 650,000

19. This is the distribution mechanism in the UAW-Ford agreement. 
hourly workers are covered by profit-sharing plans that have been established in major collective bargaining agreements since 1980, raising the coverage of such plans to 8-10 percent of workers in large bargaining units by late 1983. The share of production workers covered was 75-80 percent in the motor vehicles industry and 25-30 percent in farm and construction equipment, the two industries where the largest profitsharing plans have been negotiated. (Salaried nonproduction workers were also covered by the plans in the two industries.) Coverage in steel and the airlines was much lower. Although the number of plans in these industries has grown dramatically (in each case there was almost no profit sharing in 1980), such plans will have to be adopted by other industries if they are to influence aggregate compensation significantly.

It is not obvious that the incentives for interindustry spillovers are strong. The way in which compensation based on firm performance interferes with traditional union objectives was discussed earlier. The recent competitive pressures on unions (such as from trade and deregulation) have developed on an industry basis. There is no clear pressure for interindustry transmission. While general wage settlements have in the past often tended to spread across industries within the domain of a single union, ${ }^{20}$ there is little evidence that the performance-based compensation arrangements are following a similar path. The UAW accepts arrangements in autos but not in aerospace; the USW accepts them in steel but not in aluminum. In most instances the arrangements do not even apply to all the firms within an industry. The UAW has profitsharing arrangements with Ford and GM, but not with Chrysler (whose workers traded a plan, negotiated in 1981, in exchange for a fixed wage increase); the USW has negotiated plans with some of the smaller companies, but a proposed profit-sharing arrangement with the major steel firms that was recommended by the union's executive board in December 1982 was rejected by the bargaining council of local union presidents. A spillover of performance-based compensation systems from the union to the nonunion sector also seems dubious. The nonunion sector already has a significant labor cost advantage after a decade of more rapid wage increases in the union sector. With more frequent wage adjustments and a greater sensitivity of wages to unemployment, compensation systems in the nonunion sector are already more tightly tied (if only implicitly) to firm performance.

20. See evidence in Flanagan, "Wage Interdependence in Unionized Labor Markets." 
A second limit on the plans' effect on wage flexibility is that, in industries where plans have been negotiated, it is not obvious that profit sharing will become a large component of compensation changes in an inflationary environment. As noted, there has been no tendency to abandon COLAs in recent years. While profit-sharing arrangements might mute union wage-push (a rare phenomenon in the past two decades) or the drag of union wages in a recession, price increases from other supply-side factors would continue to influence wages and the cost structure and could dominate profit sharing as an element of compensation.

Third, the guarantees that are built into the first year of several profitsharing plans limit the extent to which pay is indexed to firm performance. Insofar as the current guarantees are a "rebate" on large recent concessions, however, they may become a less important feature of the plans in subsequent negotiations.

Finally, the scope of future profit-sharing arrangements in industries where they have been negotiated is uncertain. American employers have traditionally resisted profit-sharing plans, except during periods of economic distress. Recently, however, at least one major employer, General Motors, has considered the possibility that profits would be the main basis for future compensation. On the other hand, the UAW, which for years has advocated profit sharing as an element of the compensation package that could "benefit our members and be a useful way to settle bargaining disputes about the probable financial experience of the company during the term of a collective bargaining agreement," has stressed that profit-sharing should not be viewed as a substitute for the traditional formula of a fixed annual improvement factor plus COLA. ${ }^{21}$

Employee Stock Ownership and Worker Participation. Employee stock ownership plans (ESOPs) also spread during concession bargaining in the early 1980s; stock ownership was offered by companies as a full or partial offset to money wage concessions, including forgone

21. The 1984 UAW collective bargaining program states: profit sharing "is not a substitute for, or alternative to, other wage or benefit demands. . . Profits (and profit sharing) cannot be the basis for wages, pensions and other benefits that a worker must have reasonable assurance will be paid on a regular basis. Instead, profit sharing can be a rational way to provide equitable sharing of a company's additional productivity and efficiencies after the results of those are known and show up in its profits." Within this framework, however, the UAW indicated a willingness to negotiate new programs and improve existing plans. UAW, Resolution-1984 Collective Bargaining Program, 1984 Special Convention (Detroit: UAW, March 1984), p. 37. 
COLA payments. For example, 11,000 workers represented by the USW at the Wheeling-Pittsburgh Steel Corporation accepted shares of preferred stock in exchange for deferring benefits. Members of the Airline Pilots Association at Eastern Airlines agreed to take 17.5 percent of total pay in the form of subordinated debentures (paying 5 percent interest) that could at the employee's option later be converted into Eastern common stock. In some cases, such arrangements have resulted in employees owning a substantial fraction of the company and effectively buying the company. Members of the Food and Commercial Workers Union at the Rath Packing Company, for example, ended up owning 60 percent of the stock and acquiring management control. ESOPs, which are typically established on a deferred payment basis, offer greater tax advantages to employers than do most negotiated profit-sharing plans. They may also offer tax advantages to some high-income union members, since income earned in an ESOP trust is exempt from taxation until it is distributed. Beyond these tax aspects, the considerations governing the spread of profit-sharing plans appear to apply to ESOPs. ${ }^{22}$

Worker participation plans have generally been opposed by American unions as devices that blur the respective institutional responsibilities of labor and management. Even under recent concession bargaining, only isolated instances of worker representation on boards of directors have emerged. ${ }^{23}$ However, one would expect that the spread of compensation arrangements based on firm or company performance would increase the demand for union representation on such bodies. Concession agreements that index compensation to performance raise problems of monitoring and verification that are not present to the same degree when the wage is fixed or indexed to public information, such as the CPI. Management is likely to have better information than the union on the performance of the firm, with consequent ability to behave opportunistically in the reporting of data that will influence future compensation. In order to reduce or eliminate this natural asymmetry of information,

22. Employers may claim a tax credit for ESOP contributions up to 15 percent of the annual compensation of ESOP participants. Negotiated profit-sharing plans do not normally provide for deferred payments and hence can be deducted only from income (like other current wage payments).

23. The president of the UAW was placed on the board of directors of the Chrysler Corporation, and a concession agreement between some airline unions and Eastern Airlines resulted in the appointment of three individuals representing unions to the airline's board of directors. 
unions would rationally wish to combine performance-based compensation systems with institutional arrangements that would increase a union's ability to verify the accuracy of key performance measures. Participation on board of directors is one such mechanism. ${ }^{24}$

\section{Changes in the Legal Environment of Union-Management Relations}

The erosion of the economic influence of unions in the United States predated the recent concession bargaining. Union penetration of private employment peaked in the mid-1950s (well below the proportionate representation achieved by unions in most other Western countries) and has been declining ever since. Absolute union membership has decreased since 1978. Moreover, the decline in union membership in the private sector has been only partially offset by rapid union growth in the public sector since the mid-1960s.

Part of the decline in union representation in the private sector reflects a shift in the industrial mix of employment as jobs have moved from industries of traditional union strength-such as manufacturing, transportation, and construction-to industries in which union penetration has historically been low, such as services. Without changes in the extent of union organization by industry, these shifts alone would account for some decline in aggregate union membership. Union representation has also decreased within most industries in the private sector, however. Shifts in employment from blue-collar to white-collar jobs and from the northern and eastern states to the southern states are only partially associated with a changing industrial mix of employment. Some of the decline in union penetration within industries also reflects changes in the occupational and regional composition of employment. Again assuming no changes in the extent of union organization by occupation or by region, the effects of shifts in occupational and geographic composition that have occurred since the mid-1950s have reduced the extent of union organization within industries as well as between industries.

24. In discussing profit sharing, the UAW notes that, "Particular attention must be paid to safeguards against accounting manipulation, especially at smaller privately held companies." UAW, 1984 Collective Bargaining Program, p. 37. 
The increasing difficulties encountered by unions in trying to extend or maintain their jurisdiction is further signaled by a drop in their success rate in elections run by the National Labor Relations Board (NLRB) in which employees vote for or against union representation. In 1950 unions won about 74.5 percent of these elections, but by 1981 the success rate had dropped to 45.4 percent. At the same time there has been an increase in the number of decertification elections (in which employees vote over whether or not to remove their union as the legal bargaining representative), and the union success rate in these elections has declined from 33.0 percent in 1950 to 25.1 percent in 1981. Developments such as these have led unions to attribute some of their declining representation strength to the legal environment of labor relations and to argue for revisions in the National Labor Relations Act (NLRA), the basic statute governing labor relations in the United States. Judging by the opposition mounted by employers to relatively modest proposals for revisions of the NLRA (such as the proposed Labor Law Reform Act of 1978), management apparently shares the view that union strength is highly sensitive to small changes in the law. ${ }^{25}$ More recently, changes in the bankruptcy law have eroded the status of union contracts in certain circumstances. Since the relative power that management and labor bring to the bargaining table can be shaped by the legal as well as the economic environment of industrial relations, the roles of the NLRA and of recent changes in the Bankruptcy Code are worth exploring.

\section{UNION STRENGTH AND THE NATIONAL LABOR RELATIONS ACT}

The elaborate legal regulation of labor relations in the United States centers on the rights and obligations of unions and employers established

25. Research into the impact of the NLRA is much less clear on this point. One study found that most of the aspects of conduct during union representation campaigns that are subject to regulation by the NLRB have no bearing on the outcome of the elections. See Julius G. Getman, Stephen B. Goldberg, and Jeanne B. Herman, Union Representation Elections: Law and Reality (New York: Russell Sage Foundation, 1976). Another study found that consultants hired by employers to manage a company's resistance to union organizing attempts had little impact on the outcome of representation elections. See John Lawler, "The Impact of Management Consultants on the Outcome of Certification Elections," Industrial and Labor Relations Review (forthcoming, 1984). On the other hand, a recent study of the same data resulted in a more varied pattern of conclusions concerning the board's impact. See William T. Dickens, "The Effect of Company Campaigns on Certification Elections: Law and Reality Once Again," Industrial and Labor Relations Review, vol. 36 (July 1983), pp. 560-75. 
in the NLRA. This law establishes a basic right to concerted activity by employees; it seeks to guarantee that right (1) through election procedures by which unions may become the legal representative of workers in a particular bargaining unit and (2) through the prohibition of certain "unfair labor practices" by employers and unions that are believed to interfere with the objectives of the act. The NLRB, an independent regulatory agency, was established to oversee the election process and to investigate, prosecute, and adjudicate charges of unfair labor practices brought by unions, employers, and individual workers. ${ }^{26}$ The NLRA does not cover employees in the public sector, where collective bargaining rights are instead specified in a crazy quilt of legislation passed by state and local governments and in a federal executive order.

Over the years, the NLRB has developed a rather elaborate system of rules to implement the act's requirements that employers not discriminate against workers on the basis of their union activities or sympathies, that neither party coerce individuals in their right to join or to refrain from joining a union, that both parties bargain in good faith, and so on. As a result, the regulatory requirements that have developed out of almost fifty years of NLRB rule making are an important consideration in union organizing campaigns, collective bargaining negotiations, work stoppage activities, and the representation of individual union members by their organizations.

The ubiquitous presence of the NLRB has also fostered the view that notwithstanding some of the shifts in the composition of employment noted above, alterations in the rights established under the act could significantly alter the relative bargaining power of labor and management. Consideration of this view leads to the larger question of the real impact of the NLRB's regulatory activity on behavior and bargaining outcomes, a topic on which serious research has begun only recently. Whatever the merits of the larger debate over regulatory impact, it is clear from an examination of the numbers that union fortunes in representation and decertification elections (which might be altered by changes in the NLRA or in the policy of the NLRB) play a relatively modest role in the general decline in union representation in the United States.

In fact, there is no single factor that accounts for the decline in

26. Organizationally, the board's Office of the General Counsel, which handles investigations and prosecutions, operates independently of the board, which rules on the merits of cases brought by the general counsel. 
unionization. To a certain extent, it reflects an apparent reduction in organizing activity by unions. The percent of nonunion labor involved in certification elections declined from about 3 percent in 1950 to less than 1 percent in 1980 . Most of the decline occurred rather precipitously in the 1950s, but the decline continued at a slower rate through the 1970s. The effect of declining organizing activity during the period was reinforced by a fairly steady decline since 1950 in the union success rate in those elections that did occur. This observation is consistent with the view that increased employer resistance accounts for the decline in union fortunes, but it is also consistent with a selectivity process wherein unions first attempt to organize bargaining units in which their probability of success is highest (given employee attitudes toward union representation) and only later proceed to situations that offer a lower probability of success. As the cost per organizing effort rises over time, it is hardly surprising that the resources allocated to organizing activity declines. The fact that the percent of union workers involved in decertification elections also increased steadily during the 1970s has often been cited as a signal of the increasing difficulties faced by unions, but this appears to be a gross overinterpretation of the small numbers involved. ${ }^{27}$

\section{BANKRUPTCY AND UNION CONTRACTS}

The legal status of union contracts in the United States has also been altered in the aftermath of a revision of the Bankruptcy Code completed in the Bankruptcy Reform Act of 1978. A purpose of the revision was to add flexibility to bankruptcy proceedings in order to facilitate the reorganization and rehabilitation of economically troubled businesses. Under the previous law, a firm that wished to continue operating while in bankruptcy proceedings would have to establish that it was insolvent in order to initiate proceedings. Subsequently, trustees would have to devise a plan for the orderly reorganization of a bankrupt firm and present

27. Decertification elections involved about 0.25 percent of the unionized labor force by 1980 , leading the authors of one interesting study to observe that, "Even at its highest and if every election resulted in a decertification, it would take over 15 years for decertifications to cause a 1-percent drop in the percent of the labor force organized-all other things held constant." In fact unions during the 1970s won an average of about 50 percent of decertification elections. See William T. Dickens and Jonathan S. Leonard, "Accounting for the Decline in Union Membership," Industrial and Labor Relations Review (forthcoming, 1984). 
it to a U.S. District Court judge for approval. The revised code no longer requires a firm to demonstrate current insolvency in order to enter bankruptcy proceedings, and firms may even claim uncertain or "contingent" liabilities, such as potential claims from litigation that may not be completed at the time of a bankruptcy filing. In addition, most companies that file for protection from creditors under Chapter 11 of the revised code continue to be operated by their pre-petition managers, acting as "debtors-in-possession." While petitions for bankruptcy must be reviewed and approved by a bankruptcy court, debtors-in-possession now operate with less court supervision than occurred under the previous law. ${ }^{28}$

These developments created a clear conflict between the Bankruptcy Code and the National Labor Relations Act concerning the treatment of contracts. On the one hand, the Bankruptcy Code permits the judges of bankruptcy courts to set aside "executory contracts" in order to achieve the successful rehabilitation and reorganization of "insolvent" companies, but makes no specific mention of labor agreements. On the other, the NLRA prohibits both parties to a labor agreement from unilaterally imposing changes during a contract term, but makes no mention of bankruptcy situations. Under the special status given labor contracts by the NLRA, what standards should bankruptcy courts apply in deciding whether labor agreements could be set aside if the petition were approved?

A second issue arose when some major corporations appeared to use bankruptcy proceedings to abandon their labor agreements and the procedural requirements of U.S. labor relations law. In 1983 the Wilson Foods Corporation cited excessive labor costs in its petition for bankruptcy and cut wages by about 40 percent before the bankruptcy court ruled on the petition. Continental Airlines cut wages by more than half and resumed operations on a nonunion basis three days after filing for bankruptcy and months before a bankruptcy court would rule on the petition.

In February 1984 the U.S. Supreme Court rendered two rulings in the

28. The revision of the bankruptcy code also shifted much of the supervision of bankruptcy proceedings from federal district courts to specialized bankruptcy courts. By removing bankruptcy proceedings from the federal courts the new code diluted the institutional inclination to balance the public policy objectives of bankruptcy legislation with the conflicting public policy objectives of labor relations (and other) legislation. 
Bildisco case. In the first ruling a unanimous Court ruled that bankruptcy courts could release a company from its union contracts without requiring proof that the company would otherwise face imminent failure (the standard favored by unions). In the second ruling the Court by a 5-to-4 margin said that companies filing a petition for bankruptcy could unilaterally abrogate their labor agreements before the bankruptcy court approved their petition. ${ }^{29}$ In rejecting the standard proposed by the unions and the NLRB, the Court nevertheless held that the bankruptcy courts should adopt a "somewhat stricter" standard for rejecting union contracts than the "business judgment" standard applied to other contracts in bankruptcy proceedings. It was vague, however, on what the standard should be. ${ }^{30}$

The second part of the Bildisco decision does obvious violence to the procedures that have evolved under the NLRA for modification of collective bargaining agreements. Two facts cast doubt on whether the ruling produces a major alteration in the relative bargaining power of labor and management, however. First, in permitting bankruptcy courts to set aside union contracts under a looser and more ambiguous standard, the Supreme Court did not alter the basic representation rights of unions at firms involved in Chapter 11 proceedings. Indeed, the majority decision states that the debtor-in-possession "is obligated to bargain collectively with the employees' certified representative over the terms of a new contract pending rejection of the existing contract or following formal approval of rejection by the Bankruptcy Court." ${ }^{31}$ Second, under the NLRA employers have always had the right to hire permanent replacements for strikers (unless the strike is in response to unfair labor practices by the employer).

For example, under the Bildisco ruling, a firm may petition for bankruptcy and unilaterally impose changes that it would otherwise have sought in negotiations. ${ }^{32}$ (This is the tack taken by Continental

29. NLRB v. Bildisco and Bildisco, Supreme Court decision as printed in Bureau of National Affairs, Daily Labor Report, no. 36 (February 23, 1984), pp. D-1-D-12. The question of what happens if a bankruptcy court fails to approve the petition of a company that has set aside union contracts was not addressed.

30. The Court also required bankruptcy courts to ascertain that there had been some effort to achieve a solution through voluntary negotiations between the employer and the union(s) involved, but did not require that the bargaining go to "impasse" as does the NLRB.

31. NLRB v. Bildisco and Bildisco, p. D-7.

32. Alternatively, at some later time, the changes may be imposed by a judge of the Bankruptcy Court. 
Airlines in 1983.) The union may accept a modification of the contract. But if a union objects to the changes that have been imposed, it can initiate negotiations demanding its previous benefits (or some compromise position). Also as before, the union may strike in support of its demands in the event of an impasse (as the unions at Continental did). The outcome-including the possibility that strikers would be replaced (as they were at Continental)-will be determined by the relative bargaining power of the parties. In the absence of the Bildisco ruling the firm could request the same concessions from a union in the normal course of renegotiating a contract. The union may agree to a modification of the contract or it may resist the company's request to the point of impasse and strike to back up its demands. Eventually, the strike will end on terms that are determined by the relative bargaining power of the parties. Under the NLRA, this includes the possibility that the employers will hire permanent replacements for the strikers. (Under existing law, Continental could have proposed and held out for the same drastic pay cuts in collective bargaining negotiations, the unions could have struck, and Continental could have hired permanent replacements.) The rearrangement of rights under the Bildisco ruling alters the starting point for negotiations but not the factors that determine the ultimate outcome. ${ }^{33}$

\section{Conclusions}

The dramatic collective bargaining concessions of the early 1980s have checked and begun to reverse the growth of union wages relative to nonunion wages, but at most they are likely to have only a modest impact on the long-term flexibility of aggregate union wages. This is partially because unions are likely to demand more than the restoration of benefits as the firms that won concessions become more profitable. More important are the facts that (1) the domain of concession bargaining, while large in comparison to the past, is limited in comparison with the general scope of collective bargaining, and (2) negotiations have in large measure had little impact on the structural features of collective

33. As this was being written, Congress was deadlocked over general bankruptcy legislation. A bill in the House of Representatives includes a provision that would mitigate the Bildisco decision. Under this legislation, labor contracts could be set aside by a bankruptcy court only if retaining the contract would result in a loss of employment. A Senate bill stays closer to the Bildisco decision. 
bargaining agreements that most influence wage flexibility and the past growth of union relative wages. In particular, most contracts, including those with substantial first-year concessions, continue to include fixed deferred pay increases. In addition, neither the duration of contracts nor the prevalence of COLAs has changed in any lasting respect, and most of the reduced influence of COLAs on union wage changes in the early 1980 s can be traced to the deceleration of prices.

Whether the union-nonunion wage differential will continue to drop below its recent historical high depends on the relationship between fixed, "annual-improvement-factor" increases and productivity growth. In some of the industries, future productivity growth will depend in part on the ultimate impact of changes in work rules negotiated in the early 1980s. Barring major changes in productivity trends, a sustained decline in the union relative wage will depend on the willingness of unions to share more of the risk of uncertain future productivity movements by trading profit sharing (or other compensation measures indexed to the firm's performance) for some portion of the traditional annual improvement factor. That is, while retaining traditional contract forms, unions might negotiate smaller fixed increases than in the past but add or expand upon profit-sharing (or related) provisions to handle uncertainty over future productivity, much the way COLAs now address uncertainty over future prices.

A major novelty of recent concession negotiations has indeed been an increased interest in indexing at least part of the compensation package to firm performance. To date the interest is limited to industries in economic distress, and whether the median union worker in these industries is willing to accept a riskier compensation scheme in exchange for greater job security in the long run is itself uncertain. Some of the plans include distributional formulas that may divide high- and lowskilled workers on the desirability of retaining the plans. Moreover, adoption of such arrangements by industries that do not share the distress seems unlikely. With job security well protected by seniority arrangements, the median union voter has little incentive to accept a compensation scheme that offers a less certain income scheme. Finally, structural features of some of the profit-sharing plans appear to mute the potential wage flexibility that could result from such compensation arrangements. 


\section{Comments and Discussion}

Marvin H. Kosters: It is clear that widespread union wage concessions and contract renegotiations during the past few years were unusual developments in collective bargaining, and that these developments produced unusually small average union wage increases last year. It is much less clear, however, what these recent developments mean for future wage flexibility in the union sectors and at the macroeconomic level.

It is possible to make the case that little in the way of increased wage flexibility over the business cycle should be expected on the basis of developments we have seen so far. Bob Flanagan makes this case in his careful review of recent union wage trends, changes in provisions of contracts, and changes in the legal environment for collective bargaining. Although he makes the case well, his paper has not led me to modify my own somewhat different conclusion that I expressed in a recent paper on essentially the same subject. I want to explore why we have placed somewhat different interpretations on what recent developments suggest about long-term union wage flexibility.

There are several points on which we seem to agree. We have both, of course, looked at basically the same data. We agree that the union concessions were not exclusively attributable to cyclical forces. I also agree with Flanagan that the concessions took place in the context of little strike activity; that changes in labor law administration were probably not a significant factor; that contract duration has remained roughly unchanged; that new provisions in labor contracts will not, by themselves, introduce much more flexibility than previously; and that new provisions may not spread or even be retained over the longer term.

Where we differ is on what we mean by long-term union wage flexibility 
and where to look for clues. Flanagan's focus in this paper is primarily on union wage flexibility over the business cycle in response to cyclical changes in demand. His judgment that no marked changes in union wage flexibility should be expected is based primarily on his examination of the extent to which changes in contract provisions have been introduced that would more or less automatically provide more wage flexibility in response to demand changes. His view about where to look for clues is quite explicitly stated: "It is contractual alterations in the means by which union wages adjust to contingencies that hold the most promise for greater macroeconomic wage flexibility and a reduction in the unionnonunion wage gap." I should note, however, that he also discusses the legal environment which, with the possible exception of bankruptcyrelated issues, could be expected to influence wage behavior without regard to cyclical conditions.

In my work, I have not been primarily concerned with union wage flexibility over the business cycle. Instead, my interest has been in whether recent developments suggest increased responsiveness of union wages to underlying economic conditions, particularly in industries in which wage levels appear to be seriously out of line with what might be expected in competitive markets. As a consequence, I have been interested in flexibility in terms of adjustments in relative wages over periods longer than the business cycle. My emphasis has been on what has happened to competition in product markets and how collective bargaining as an institution has coped with the introduction of increased competition. To make a judgment about what recent experience suggests about union wage flexibility, I have looked at a range of union responses broader than changes in contract provisions.

I disagree somewhat with Flanagan's view that recent experience is "in large measure more an extension than a break with past union wage behavior." As evidence of a break with the past, I would point to several instances of renegotiation of contracts before they were scheduled to expire, agreement to give up or defer scheduled wage or benefit increases, readjustment of long-term contract formulas (at least temporarily), and an increased frequency of departure from common, industry-wide contract arrangements. Perhaps the most notable, and perhaps unexpected, break with past practices is the emergence of agreements providing differentially lower wages for newly hired workers. Increased attention is apparently being given to modification of work rules to reduce labor costs, and increased emphasis is being placed on cooperative labor- 
management efforts to seek mutually agreeable arrangements in areas where interests may diverge less sharply than on rates of pay. How significant or durable these departures are is uncertain, of course, but I have been impressed with the inventive ways in which bargaining practices have adapted to changes in the competitive environment.

I see the timing and size of union wage concessions as influenced importantly by the recent long recession. But their occurrence is a fact I attribute mainly to the pressures of competition on union wage premiums, premiums that had been expanding during the 1970s. In other words, I see what happened in several major union labor markets as derivative of what happened to competition in product markets, mainly deregulation in transportation industries and stronger competition from international sources.

I see prospects for union wage flexibility in the future as contingent, therefore, on what happens to competition in product markets and service markets. It seems to me that some of the adjustments that have occurred are only initial steps toward more realistic wage levels and that some of these adjustments are nowhere near completion. In the telephone communications area, for example, growing pressures for adjustment seem likely. In sectors affected by international trade, further adjustments will depend on our trade policies. Although the kind of union wage flexibility that I have in mind here is not, strictly speaking, increased flexibility over the business cycle, I would expect some cyclical pattern because pressures for adjustment will be more pronounced during recession.

I should concede, perhaps, that I am not satisfied that I can explain the rise in union wage premiums in several sectors during the 1970s; inertia in wage-setting formulas and practices may have been a factor. Also, I would not pretend to be able to specify precisely the size and pattern of normal, equilibrium union wage premiums; I am persuaded, however, that whatever such levels are, they were significantly exceeded in the recent past in several industries. Evidence pointing in this direction includes shrinking union shares in partially unionized industries and declining competitiveness in some very highly unionized activities. The introduction of differentially lower pay for newly hired workers in several instances, with employers apparently having no difficulty in attracting new workers at these lower pay levels, is also consistent with this view.

I am inclined to agree with Flanagan's view that there is little reason to expect increased wage flexibility over the business cycle as a result 
of new provisions in collective bargaining agreements that link pay to changes in performance of firms. My presumption is that maintaining a degree of stability in wage trends over the business cycle in cyclically sensitive industries will continue to be an important union goal, as it seems to have been in the past. Consequently, I am inclined to view the limited changes that we have seen in this direction as an effort to offset or disguise wage concessions to make them more palatable to the union membership. It is my impression, for example, that the essential purpose of union ownership arrangements, in particular, has been to bring about significant adjustment to lower wages. This may be less true for profitsharing or stock-accumulation plans historically, but in many recent concession situations it seems more appropriate to view these plans as offsets to or rebates on the concessions than as initiatives in pursuit of union bargaining goals.

In summary, like Flanagan I see little in recent union labor market developments that will introduce increased wage flexibility in a systematic or mechanical way over the business cycle. But I do see increased union wage flexibility resulting from more competition, and I expect the timing of adjustments in union wage trends-both up and down-to be affected by the cycle. It is important not to exaggerate the macroeconomic implications of this increased union wage flexibility, however, in view of the relatively small and generally declining share of the workforce represented by major unions.

\section{General Discussion}

James Duesenberry observed that models of wage behavior that stressed product market conditions were advanced forty years ago by John Dunlop and that instances of wage concessions when industries were in exceptional financial trouble could be found throughout the postwar period. He interpreted the low end of the Phillips curve as reflecting not the unemployment situation but the correlation between unemployment and the number of industries that were in serious financial trouble. In recent years such situations went from being isolated exceptions to being so widespread as to become a notable feature in overall union wage developments. The length and depth of the recession was one reason. But the rise in foreign competition in some sectors and the increased competition as a result of deregulation in others may have 
been equally important in creating this situation. Because these new sources of competition will still be present as an economic recovery proceeds, Duesenberry reasoned that the pressure on union wages will continue. If, as a result, the relative wages of unions have stopped rising, the prospects for inflation could be better than a simple cyclical model would suggest. Wynn Bussmann added that in most durable goods industries, the recession was barely interrupted by the brief economic rebound in late 1980 and early 1981 . Union employment was depressed for three or even four years in many durable goods industries, and the recovery that is finally occurring is still relatively weak among union workers, even in areas, such as autos, where subcontractors are often nonunion. He concluded that the union wage differential was unlikely to widen again, as it had during the 1970s, and the inflationary pressure from that source will be absent.

Robert Hall emphasized that two-tier wage systems, which were showing up in some especially hard-pressed industries such as airlines, achieved desirable allocational effects by permitting the firm to employ the efficient level of labor while still preserving the earnings premium of existing union employees. This arrangement eases the tension between higher wages and fewer jobs that normally confronts a union in deciding on its wage demands. Given that two-tier arrangements have come into existence and have this desirable property, Hall was puzzled that unions are losing decertification elections even though a two-tier arrangement would be unambiguously good for existing union members. Marvin Kosters observed that such arrangements would have only small effects in an industry, such as automobiles, where the trend of employment was downward so that there would be few new workers hired to make up the second tier. By contrast, in an industry with a lot of turnover or one in which employment is expanding substantially, lower wages for a second tier of new workers might be a sustainable situation for a time, until the number of new workers became large enough to acquire political power. Once a significant proportion of workers were in the bottom tier, Kosters reasoned, management could offer them a wage increase in exchange for getting rid of the premium enjoyed by the senior workers. Thus he found it hard to see the two-tier system lasting for very long. Robert Flanagan added that two-tier contracts are not new; but because they ultimately threaten the senior workers as they lose political power within the union, they have a desire to eliminate them when economic conditions in the industry permit. 